\title{
Illustration Graphic Art Publication and Audiovisual Service Shared Resource
}

National Cancer Institute

\section{Source}

National Cancer Institute. Illustration Graphic Art Publication and Audiovisual Service

Shared Resource. NCI Thesaurus. Code C39423.

The Art Services Shared Resource supports Cancer Center members by providing advice, customized design, and reproduction services to meet the needs of individual scientists, departments and educational programs for art, computer-imaging, graphics and photography services, including needs for scientific publications and presentations, printing, and audiovisual media. 